4. Kujan O, Sloan P. Dilemmas of oral cancer screening: an update. Asian Pac J Cancer Prev 2013; 14: 3369-3373.

5. Hirshberg A, Shnaiderman-Shapiro A, Kaplan I, Berger R. Metastatic tumours to the oral cavity pathogenesis and analysis of 673 cases. Oral Oncol 2008; 44: 743-752.

6. Kumar G, Manjunatha B. Metastatic tumors to the jaws and oral cavity. J Oral Maxillofac Pathol 2013; 17: 71-75.

7. Lim S-Y, Kim S-A, Ahn S-G et al. Metastatic tumours to the jaws and oral soft tissues: a retrospective analysis of 41 Korean patients. Int J Oral Maxillofac Surg 2006; 35: 412-415.

8. Allon I, Pessing A, Kaplan I, Allon D M, Hirshberg A Metastatic tumors to the gingiva and the presence of teeth as a contributing factor: a literature analysis. J Periodontol 2014; 85: 132-139.

9. Shen M-L, Kang J, Wen Y-L et al. Metastatic tumors to the oral and maxillofacial region: a retrospective study of 19 cases in West China and review of the Chinese and English literature. J Oral Maxillofac Surg 2009; 67: 718-737.

10. Luke C, Koczwara B, Karapetis C et al. Exploring the epidemiological characteristics of cancers of unknown primary site in an Australian population: implications for research and clinical care. Aust N Z J Public Health 2008; 32: 383-389.

11. Seoane J, Van der Waal I, Van der Waal RI F et al. Metastatic tumours to the oral cavity: A survival study with a special focus on gingival metastases. J Clin Periodontol 2009; 36: 488-492.

12. Curien R, Moizan H, Gerard E. Gingival metastasis of a bronchogenic adenocarcinoma: Report of a case. Oral Surg Oral Med Oral Pathol Oral Radiol Endod 2007; DOI: 10.1016/j.tripleo.2007.06.021.
13. D'Silva N, Summerline D-J, Cordell K G et al. Metastatic tumors in the jaws. A retrospective study of 114 cases. I Am Dent Assoc 2006; 137: 1667-1672.

14. Clausen F, Poulsen H. Metastatic carcinoma to the jaws. Acta Pathol Microbiol Scand 1963; 57: 361-374.

15. Coleman R. Clinical features of metastatic bone disease and risk of skeletal morbidity. Clin Cancer Res 2006; DOI: 10.1158/1078-0432.CCR-06-0931

16. Brown J E, Cook R J, Major P et al. Bone turnover markers as predictors of skeletal complications in prostate cancer, lung cancer, and other solid tumors. J Natl Cancer Inst 2005; 97: 59-69.

17. Hirshberg A, Berger R, Allon I, Kaplan I. Metastatic Tumors to the Jaws and Mouth. Head Neck Pathol 2014; 8: 463-474.

18. Hirshberg A, Buchner A. Metastatic tumours to the oral region. An overview. Eur J Cancer B Oral Oncol 1995; 31: 355-360.

19. Anil S, Lal P M, Gill D S, Beena V T. Metastasis of thyroid carcinoma to the mandible. Case report. Aust Dent J 1999; 44: 56-57.

20. White S, Pharoah M. Oral Radiology Principles and Interpretation. 4th ed. St Louis: Mosby. 2000.

21. Penarrocha Diago M, Bagan Sebastián J V, Alfaro Giner A, Escrig Orenga V. Mental nerve neuropathy in systemic cancer. Report of three cases. Oral Surg Oral Med Oral Pathol 1990; 69: 48-51.

22. Gaver A, Polliack G, Pilo R, Hertz M, Kitai E. Orofacia pain and numb chin syndrome as the presenting symptoms of a metastatic prostate cancer. J Postgrad Med 2002; 48: 283-284.

23. Cardoso C, Barros C, Curra C et al. Radiographic Findings in Patients with Medication-Related
Osteonecrosis of the Jaw. Int J Dent 2017; DOI: 10.1155/2017/3190301.

24. Sacco R, Woolley J, Yates J, Calasans-Maia M D, Akintola O, Patel V. A systematic review of metastatic cancer presenting in osteonecrosis of the jaws (MC-ONJ) in patients undergoing antiresorptive and/ or antiangiogenic therapy for skeletal-related adverse events. Oral Surg Oral Med Oral Pathol Oral Radiol 2021; 131: $650-659$.

25. NICE. Head and neck cancers recognition and referral. 2020. Available at https://cks.nice.org.uk/topics/headneck-cancers-recognition-referral/ (accessed November 2021).

26. Brocklehurst P, Pemberton M N, Macey R, Cotton C, Walsh T, Lewis M. Comparative accuracy of different members of the dental team in detecting malignant and non-malignant oral lesions. Br Dent J 2015; 218: 525-529.

27. Sánchez Aniceto $G$, García Peñín A, de la Mata Pages R, Montalvo Moreno J J. Tumors metastatic to the mandible: analysis of nine cases and review of literature. J Oral Maxillofac Surg 1990; 48: 246-251.

28. The Royal College of Surgeons of England/The British Society for Disability and Oral Health. The Oral Management of Oncology Patients Requiring Radiotherapy, Chemotherapy and/or Bone Marrow Transplantation. 2018. Available at https://www. rcseng.ac.uk/-/media/files/rcs/fds/publications/ rcs-oncology-guideline-update--v36.pdf (accessed November 2021).

29. Patel V, Patel S, Grossman S, Wali R. The presenting status of solid tumours with bone metastases requiring bone-targeting agents. Part 4: Miscellaneous cancers. Br Dent J 2022; in press.

\title{
Correction to: Dental practices encouraged to make a pink purchase
}

The original article can be found online at https://doi.org/10.1038/s41415-021-3650-3

Author's correction note:

Dental products and services. Br Dent J 2021; 231: 598.

An incorrect version of this product news item was sent to the journal in error and published.

The following section 'The group is urging people to be a part of the $15^{\text {th }}$ anniversary of the highly successful Practice Pink campaign. Created as a global programme in the fight against cancer, to date it's raised a significant 1.7 billion dollars for cancer charities. Across the world, these charities work within prevention and detection, life-saving research and programmes to support people with cancer' should have read 'The group is urging people to be a part of the $15^{\text {th }}$ anniversary of the highly successful Practice Pink campaign. Created as a global programme in the fight against cancer, to date it's raised a significant 1.7 million dollars for cancer charities. Across the world, these charities work within prevention and detection, life-saving research and programmes to support people with cancer.' 